А. ЛУКИЕНКО (г. Киев), А. СМИРНОВ, В. КОРОБКИН (г. Алматы, Казахстан), Т. ГИОРГОБИАНИ (г. Тбилиси, ГрУзия)

9 мая 2013 г. исполнилось бы 80 лет члену-корреспонденту НАН Украины, академику АН Республики Казахстан, лауреату государственныхпремий СССР и Украины в области науки и техники, члену многочисленных международных и украинских комитетов и комиссий, доктору геолого-минералогических наук, профессору Евгению Ивановичу Паталахе. Он ушел из жизни 31 марта 2006 г. на 73-м году. Наука потеряла выдающегося ученого-геолога, творца новых научных направлений и школ.

Е.И. Паталаха вел активные исследования в областях региональной геологии, металлогении, рудной и нефтегазовой геологии, региональной и морфологической тектоники, геодинамики, структурных методов анализа. В каждом из отмеченных направлений он проявлял высокий профессионализм, большую глубину научных знаний, генерировал новые идеи и получал принципиально новые результаты.

Евгений Иванович Паталаха прошел интересный путь производственной и научной геологической деятельности. В 1956 г. после окончания Новочеркасского политехнического института он, миновав все промежуточные должности, возглавил большую геолого-разведывательную партию в Восточном Казахстане, которая разведывала урановые месторождения. В 1959 г. начал работать в Институте геологических наук АН КазССР с 1975 по 1992 год был одним из руководителем этого учреждения. В 36 лет он защитил докторскую диссертацию.

В научной деятельности Евгения Ивановича Паталахи четко обозначились две вехи. Первый период, казахстанский, охватывает с 1956 по 1992 год, на протяжении которых Евгений

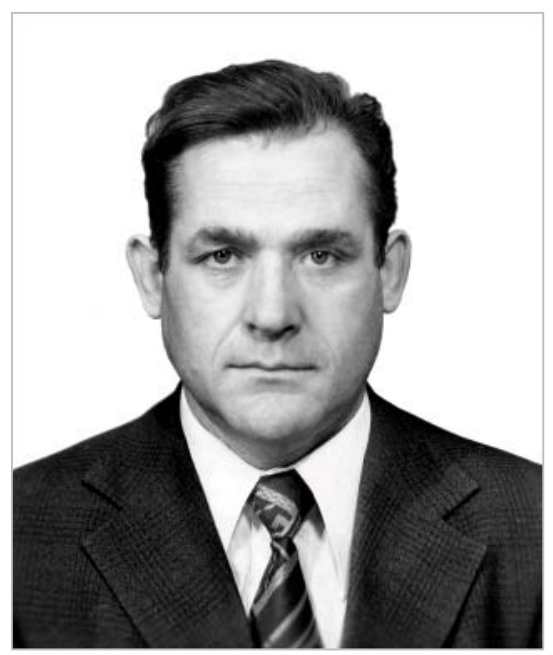

\section{Е.И. Паталаха}

Иванович состоялся как ученый мирового уровня, достиг своих самых значительных, а в отдельных направлениях выдающихся научных результатов. Его исследования в области региональной геологии, металлогении и тектоники Казахстана изложены в ряде работ, в том числе монографий: «Геология и металлогения Успенской тектонической зоны» (1967-1968; т. 1-6), «Геология и металлогения Чу-Илийского региона» (1981; т. 1, 2), «Проблемы тектоники Казахстана» (1981), «Геодинамика земной коры Казахстана» (1985). Выполнен глубокий анализ геологического строения и металлогении Казахстанского региона, на основе чего найдены новые решения геологического развития данного региона с позиции современных геотектонических концепций и оригинальных тектонических идей. Определена важная роль плюмтектоники и рифтогенеза в развитии земной коры Казахстанского региона. В 1985 г. исследования в отмеченных направлениях были оценены Государственной премией СССР.

Особое место в научной деятельности ученого в этот период занимали исследования в области морфологической тектоники. В 1970 г. он опубликовал работу «Механизм возникновения структур течения в зонах смятия», которая стала базовой для последующих исследований в области структурной тектоники земной коры. По результатам полевых и экспериментальных исследований с привлечением данных механики сплошных сред, физики твердого тела, гидродинамики и других наук на примере палеозойских зон смятия Казахстана было показано, что важную роль при структурообразовании в таких зонах играет тектоническое течение слоистых толщ, которое реализуется как комплексное, динамометаморфическое явление. Фактически впервые в структурной геологии было сформулировано представление о структурно-динамометаморфическом парагенезе: комплексе специфических структурных элементов (складок ламинарного течения, кливажа и сопряженных с ним метаморфических изменений пород, линейности, будинаже, жилах альпийского типа и других структурных и вещественных формах). На этой научной основе им была создана структурная школа, которая использовала наработки относительно механизмов реализации дислокационных процессов, а также качественноколичественной их оценки. Была активизирована экспериментальная база по моделированию процессов структурообразования и развернуты масштабные полевые исследования. В результате был создан тектонофациальный анализ - современная концепция 
дислокационного процесса и методология качественно-количественной оценки дислокационных преобразований горных пород и геологических сред. Важной составляющей этого анализа стал метод тектонофаций, использование которого позволяет определять относительные степени деформационных преобразований пород по десятибалльной шкале с учетом РТ-условий, реологических свойств геологических сред и механизмов дислокационных преобразований пород.

Результаты исследований в области морфологической тектоники и тектонофациального анализа опубликованы в огромном количестве статей, в том числе в 20 монографиях, среди которых фундаментальное значение приобрели следующие работы: «Генетические типы складчатости» (1974), «Структурный анализ линейной складчатости на примере Каратау» (1975), «Генетические основы морфологической тектоники» (1981), «Тектонофациальный анализ складчатых сооружений фанерозоя» (1986), «Введение в морфологическую тектонику» (1986), «Тектонофации мезозоны: Атлас микроструктур» (1987), «Тектонофациальный анализ и его роль в геологии, металлогении и геофизике» (1989) и др. Этот метод нашел признание широкой научной общественности, его используют при решении тектонических задач, изучении структур рудных районов и месторождений, а также геологическом картировании и выполнении ряда других геологических работ. Составлена тектонофациальная карта Казахстана масштаба 1:1 500000 («Тектонофации Казахстана» (1986).

В Украине Е.И. Паталаха работал с 1992 г. Его исследования в этом регионе также отличались многообразием задач и, что очень важно, оригинальностью найденных решений. В 1996 г. была опубликована монография «Тектонические потоки как основа понимания геологических структур», в которой были подведены итоги отмеченных многолетних тектонофациальных исследований в Казахстане и начатых в Украине. В этой работе геологической научной общественности была представлена концепция тектонического потока как инициатора и формы структурного преобразования литосферы. С этих позиций был подготовлен и опубликован ряд оригинальных работ, касающихся реологических механизмов и термодинамических условий формирования дислокационной тектоники Украинского щита, Горного Крыма и Карпат.

Большое внимание в последнее десятилетие своей научно-исследовательской деятельности Е.И. Паталаха уделил проблеме строения и развития нефтегазоносных районов Украины. Исследования были посвящены поясу фанерозойских орогенов, которые окружают Украинский щит с юго-запада (Горный Крым, Северная Добруджа, Восточные Карпаты) совместно с фронтальным поясом краевых прогибов (Балтийско-Днестровский, Преддобруджский, Каркинитский, ИндолоКубанский и др.), а также эпизодически - Черноморская субокеаническая депрессия. Особое внимание ученый сосредоточил на акватории Черного моря, рассматривая ее как важный тектонотип, с перспективными месторождениями нефти и газа. По мнению Е.И. Паталахи, в осадочных наслоениях этой депрессии сосредоточенные колоссальные скопления углеводородов. Исследования по этой проблеме были изложены в монографиях «Проблемы краевых прогибов и прогноз УВ» (2002)., «Элементы геодинамики Карпат. Прогноз углеводородов и сейсмоопасности» (2003), «Инденторный механизм в геодинамике КрымскоЧерноморского региона. Прогноз УВ и сейсмоопасности» (2003) и других многочисленных публикациях. Исследования в нефтегазовой отрасли были оценены (посмертно) Государственной премией в области науки и техники Украины.

Ученики и последователи Евгения Ивановича Паталахи продолжают внедрять и разрабатывать тектонофациальный анализ в Украине, России, странах Средней Азии, в Кавказском и других регионах мира. Учебные курсы по тектонофациальному анализу читают в Киевском национальном университете имени Тараса Шевченко, вузах России, Казахстана.

Научное наследие Евгения Ивановича Паталахи составляет около 500 работ, в том числе 30 монографий. Он подготовил плеяду учеников в первом и втором поколениях. Светлая память о нем хранится в сердцах его учеников, последователей, коллег по работе, друзей. 